\title{
OR-66
}

\section{Anti-Inflammatory Activities of Extracts from Quassia Borneensis Noot. (Simaroubaceae)}

\author{
Firdaus Kamarulzaman ${ }^{1}$, Ahmad Rohi Ghazali ${ }^{1, *}$ and Julenah Ag Nuddin ${ }^{2}$ \\ ${ }^{1}$ Biomedical Science Programme, School of Diagnostic \& Applied Health Sciences, Faculty of Health Sciences, \\ Universiti Kebangsaan Malaysia, 50300, Kuala Lumpur, Malaysia; ${ }^{2}$ Faculty of Applied Sciences, Universiti Teknologi \\ MARA, 88997, Kota Kinabalu, Sabah, Malaysia;E-mail: rohi@fskb.ukm.my
}

\begin{abstract}
Simaroubaceae family had been reported to possess numerous biological activities due to the presence of quassinoids. This study was carried out to assess the potential anti-inflammatory properties of extracts from Quassia borneensis, an unexplored indigenous plant from Sabah. Bark and root samples of $Q$. borneensis were soxhlet or macerated in methanol and partitioned with n-hexane, chloroform and water to yield hexane, chloroform and aqueous extracts, respectively. Anti-inflammatory activity was evaluated from the production of nitric oxide following treatment of extracts on lipopolysaccharide-stimulated RAW 264.7 murine macrophage cells using Griess assay. Expression of inflammatory protein was detected by immunoblotting. Results showed that the chloroform extract of $Q$. borneensis root demonstrated the most potent inhibition of nitric oxide production with $\mathrm{IC}_{50} 0.3 \mu \mathrm{g} / \mathrm{ml}$. In conclusion, $Q$. borneensis possessed anti-inflammatory activity and have a potential to be further developed as chemopreventive agent.
\end{abstract}

Keywords: Quassia borneensis, Simaroubaceae, anti-inflammation, nitric oxide, Griess assay. 